ISSN 1392-3196 / e-ISSN 2335-8947

Zemdirbyste-Agriculture, vol. 104, No. 2 (2017), p. 131-138

DOI 10.13080/z-a.2017.104.017

\title{
Barley undersown with red clover in organic and conventional systems: nitrogen aftereffect on legume growth
}

\author{
Maarika ALARU, Liina TALGRE, Anne LUIK, Berit TEIN, Viacheslav EREMEEV, \\ Evelin LOIT \\ Institute of Agricultural and Environmental Sciences, Estonian University of Life Sciences \\ Fr. R. Kreutzwaldi 1, Tartu, Estonia \\ E-mail: maarika.alaru@emu.ee
}

\begin{abstract}
Nitrogen $(\mathrm{N})$ deficiency is a major problem in organic and low-input farming systems. Growing spring cereals with undersown legumes has a positive effect on soil fertility, enriching it with nitrogen, through symbiosis of legumes with nodule bacteria. Two hypotheses were tested: 1) undersowing of red clover increases the protein content of barley grains and 2) mineral $\mathrm{N}$ has negative aftereffect on growth of legume plants. The aim of this study was to investigate the effect of organic (cattle manure, off-season cover crop) and mineral $\mathrm{N}$ in organic and conventional farming systems on (i) barley (Hordeum vulgare L.) grain yield and quality, (ii) biomass yield formation of undersown red clover (Trifolium pratense L.) and (iii) the aftereffect of mineral and organic $\mathrm{N}$ fertilisers on the red clover crop biomass yield in the following year. The experiment was established in 2008 at the Estonian University of Life Sciences $\left(58^{\circ} 22^{\prime}\right.$ N, $26^{\circ} 40^{\prime}$ E) on the soil described as Stagnic Albic Luvisol (LV ab-st) (WRB, 2014) with sandy loam surface texture, $1.38 \% \mathrm{C}, 0.13 \% \mathrm{~N}, 133 \mathrm{mg} \mathrm{kg}^{-1} \mathrm{P}, 210 \mathrm{mg} \mathrm{kg}^{-1} \mathrm{~K}_{\text {and }} \mathrm{pH}_{\mathrm{KCl}} 6.0$. The crops were treated using different farming systems: three organic (Org0, OrgI and OrgII) and four conventional (N0, N40, N80 and $\mathrm{N} 120$ ); nitrogen sources during crop cycle period: $\mathrm{N} 0$ and $\mathrm{Org} 0=$ symbiotically fixed atmospheric $\mathrm{N}_{2}, \mathrm{~N}_{40}=\mathrm{N}_{2}$ + mineral $\mathrm{N} 40 \mathrm{~kg} \mathrm{ha}^{-1} \mathrm{~N}, \mathrm{~N} 80=\mathrm{N}_{2}+$ mineral N $80 \mathrm{~kg} \mathrm{ha}^{-1} \mathrm{~N}, \mathrm{~N} 120=\mathrm{N}_{2}+$ mineral N $120 \mathrm{~kg} \mathrm{ha}^{-1} \mathrm{~N}, \mathrm{OrgI}=\mathrm{N}_{2}$ $+\mathrm{N}$ taken up by cover crops $\left(\mathrm{N}_{\mathrm{CC}}\right)$ and $\mathrm{OrgII}=\mathrm{N}_{2}+\mathrm{N}_{\mathrm{CC}}+\mathrm{N}$ applied with manure $\left(\mathrm{N}_{\mathrm{m}}\right)$. Our study revealed that grain yield of barley was strongly affected by undersown red clover; because of competition for nutrients in cereallegume mixture the grain yield of barley in organic system was 11-61\% lower than that in conventional system. The seed rate of undersown red clover (2.84 million viable seed per ha) was too high. The content of protein depended on the availability of mineralised nitrogen. The mean protein content of barley grains over the trial years and treatments was $99 \pm 1.6 \mathrm{~g} \mathrm{~kg}^{-1}$ in the conventional system, which was $17 \%$ higher than that in the organic system. Undersowing of red clover had no significantly positive effect on the grain yield and protein content of barley. Mineral N fertiliser had no negative aftereffect on growth of the red clover crop the following year. Mean above ground biomass yield over the trial years for the red clover crop $2^{\text {nd }}$ cut was $17 \%$ higher in the conventional system than in the organic system.
\end{abstract}

Key words: competition for nutrients, protein content of cereal, sowing rate and time.

\section{Introduction}

Nitrogen $(\mathrm{N})$ deficiency is a major problem in organic and low-input farming systems. Well mineralised cow manure and winter cover crops as green manure are used in organic farming to save soil fertility and enrich it with nitrogen (Chinthapalli et al., 2015). In addition to that, growing spring cereals with undersown legumes is considered to have a positive effect on soil fertility, enriching it with nitrogen, through symbiosis of legumes with nodule bacteria, and with organic matter due to the huge amount of crop residue left behind (Knudsen et al., 2004; Song et al., 2007). For stockless organic arable farms the cultivation of legumes is the most important source of nitrogen (Fuchs et al., 2008). Several studies have found that cultivation of cereals with undersown legumes increases protein content in the seeds of the cereal component, increases the yield and content of crude protein in the above ground biomass (HauggaardNielsen et al., 2008; Pridham, Entz, 2008; Corre-Hellou et al., 2011). Compared with other major agricultural regions in the world, the European Union dedicates a relatively small area to legume crops and this has even decreased in recent decades. With regard to the potential ecosystem services delivered by legumes, there has been an increasing demand to strengthen the role of legumes

Please use the following format when citing the article:

Alaru M., Talgre L., Luik A., Tein B., Eremeev V., Loit E. 2017. Barley undersown with red clover in organic and conventional systems: nitrogen aftereffect on legume growth. Zemdirbyste-Agriculture, 104 (2): 131-138 DOI 10.13080/z-a.2017.104.017 
in farming systems and agri-food/feed chains to meet agronomic, environmental and economic objectives.

The formation and level of cereal grain yield have been strongly affected by the sowing rate of cereal and undersown legume and by the availability of mineralised nitrogen at early stages of cereal plants. The competition for light, water and nutrients is a decisive factor for formation of above ground biomass and grain yield of different components in mixtures (Anderson, Garlinge, 2000). A reduced rate of mineral nitrogen fertiliser is used for mixtures of cereals with legumes in conventional farming. In the study with soybean Ohyama et al. (2012) found that the development and nitrogen fixation activity of legume root nodules are suppressed when nodulated roots are exposed to a high concentration of mineral nitrogen. However, there is a lack of information about the aftereffects of high mineral $\mathrm{N}$ on the growth of the red clover crop the following year.

Two hypotheses were tested: 1) the undersowing of red clover increases the protein content of barley grains and 2) mineral $\mathrm{N}$ has a negative aftereffect on growth of legume plants. The aim of this study was to investigate the effect of organic (well composted cow manure and cover crops as green manure) and mineral $\mathrm{N}$ in organic and conventional farming systems on (i) barley (Hordeum vulgare L.) grain yield, (ii) biomass yield formation of undersown red clover (Trifolium pratense L.) and (iii) the aftereffect of mineral and organic $\mathrm{N}$ fertilisers on the red clover crop biomass yield in the following year.

\section{Materials and methods}

Experimental design. This investigation was conducted in a long-term field crop rotation experiment comparing organic and conventional growing systems (Alaru et al., 2014). The experiment was established in 2008 at the Estonian University of Life Sciences (58 $22^{\prime}$ $\mathrm{N}, 26^{\circ} 40^{\prime}$ E) on the soil described as Stagnic Albic Luvisol (LV ab-st) (WRB, 2014), with sandy loam surface texture, $1.38 \% \mathrm{C}, 0.13 \% \mathrm{~N}, 133 \mathrm{mg} \mathrm{kg}^{-1} \mathrm{P}, 210 \mathrm{mg} \mathrm{kg}^{-1}$ $\mathrm{K}$ and $\mathrm{pH}_{\mathrm{KCl}}$ 6.0. It was set up in a systematic block design with four replicates of each treatment and a plot size of $60 \mathrm{~m}^{2}$. The trial has a five-year crop cycle period during which five different crops follow each other in the order: barley (Hordeum vulgare L.) with undersown red clover $\rightarrow$ red clover (Trifolium pratense L.) $\rightarrow$ winter wheat (Triticum aestivum L.) $\rightarrow$ pea (Pisum sativum L.) $\rightarrow$ potato (Solanum tuberosum L.). In this study, only barley with undersown red clover and red clover crop yields and yield quality were investigated. The data of this study related to the period of 2012-2015, during which three two-year periods were investigated (grain and biomass yield formation and yield of barley and red clover) (Table 1). The barley and red clover cultivars used were 'Anni' and 'Jõgeva 205', respectively, sown at 3.75 and 2.80 million viable seeds per ha. Both cultivars have been bred at the Estonian Plant Breading Institute and are widely grown in Estonia.

Table 1. Crop rotation (one replication) and nitrogen $(\mathrm{N})^{*}$ amounts applied to different organic and conventional treatments

\begin{tabular}{|c|c|c|c|c|c|c|c|c|c|}
\hline \multirow[t]{2}{*}{ Year } & \multirow[t]{2}{*}{ Crop } & \multicolumn{4}{|c|}{$\begin{array}{l}\text { Mineral } \mathrm{N} \text { applied } \mathrm{kg} \mathrm{ha}^{-1} \\
\text { to conventional treatments }\end{array}$} & & \multicolumn{3}{|c|}{$\begin{array}{c}\text { Organic } \mathrm{N} \text { applied with } \\
\text { cattle manure } \\
\mathrm{kg} \mathrm{ha}^{-1}\end{array}$} \\
\hline & & No & N40 & $\mathrm{N} 80$ & N120 & & Org0 & OrgI & OrgII \\
\hline 2012 & barley + red clover $(1)$ & 0 & 40 & 80 & 120 & protective & 0 & 0 & 46 \\
\hline \multirow{2}{*}{2013} & red clover $(1)^{* *}$ & 0 & 0 & 0 & 0 & area & 0 & 0 & 0 \\
\hline & barley + red clover $(2)$ & 0 & 40 & 80 & 120 & & 0 & 0 & 54 \\
\hline \multirow[t]{2}{*}{2014} & red clover $(2)$ & 0 & 0 & 0 & 0 & protective & 0 & 0 & 0 \\
\hline & barley + red clover $(3)$ & 0 & 40 & 80 & 120 & area & 0 & 0 & 47 \\
\hline 2015 & red clover $(3)$ & 0 & 0 & 0 & 0 & & 0 & 0 & 0 \\
\hline
\end{tabular}

* $-\mathrm{N}$ sources during crop cycle period: $\mathrm{N} 0$ and $\mathrm{Org} 0=$ symbiotically fixed atmospheric $\mathrm{N}_{2}, \mathrm{~N} 40=\mathrm{N}_{2}+$ mineral $\mathrm{N} 40 \mathrm{~kg}$ ha ${ }^{-1} \mathrm{~N}, \mathrm{~N} 80$ $=\mathrm{N}_{2}+$ mineral $\mathrm{N} 80 \mathrm{~kg} \mathrm{ha}^{-1} \mathrm{~N}, \mathrm{~N} 120=\mathrm{N}_{2}+$ mineral N $120 \mathrm{~kg} \mathrm{ha}^{-1} \mathrm{~N} ; \operatorname{OrgI}=\mathrm{N}_{2}+\mathrm{N}$ taken up by cover crops $\left(\mathrm{N}_{\mathrm{CC}}\right), \operatorname{OrgII}=\mathrm{N}_{2}+$ $\mathrm{N}_{\mathrm{CC}}+\mathrm{N}$ applied with manure $\left(\mathrm{N}_{\mathrm{m}}\right)$; ** $-(1)$ - the first two-year period (2012-2013), (2) - the second two-year period (2013-2014), (3) - the third two-year period

The crops were cultivated in different farming systems: three organic (Org0, OrgI and OrgII) and four conventional (N0, N40, N80 and N120) treatments (Table 1). The first organic treatment Org0 was a control, with symbiotically fixed atmospheric $\mathrm{N}_{2}$ the only source of $\mathrm{N}$, ploughed into the soil with legume above-ground biomass. In the second organic treatment OrgI, in addition to legume, a cover crop of winter rye (Secale cereale L.) was sown as green manure in winter before the barley with undersown red clover. The cover crop was ploughed into the soil as soon as possible after the snow melted in April. In the third organic treatment OrgII, fully composted cattle manure was added in early spring at a rate of $10 \mathrm{t} \mathrm{ha}^{-1}$. The organic $\mathrm{N}$ amounts applied with manure at this rate are presented in Table 1 . The amounts of phosphorus and potassium ranged between 8-18 $\mathrm{kg} \mathrm{ha}^{-1} \mathrm{P}$ and $32-43 \mathrm{~kg} \mathrm{ha}^{-1} \mathrm{~K}$, respectively.
Nitrogen source of the first conventional treatment N0 was the same as for the Org0 treatment, i.e. atmospheric $\mathrm{N}_{2}$ fixed by legumes in crop rotations; mineral $\mathrm{N}$ fertilisers were not added. The other three conventional treatments N40, N80 and N120, had additional N-P-K fertilisers applied at sowing at a rate of 20-25-95 kg ha-1, whereas the amounts of $\mathrm{P}$ and $\mathrm{K}$ were similar in all treatments. Corre-Hellou et al. (2011) reported that legume-cereal mixtures are treated with lower doses of nitrogen fertiliser than cereal only crops, which are advantageous from an economic point of view. One and/or two subsequent $\mathrm{N}$ supplements were added during growth $\left(\mathrm{N} 40=20 \mathrm{~kg} \mathrm{ha}^{-1} \mathrm{~N}, \mathrm{~N} 80=40+20 \mathrm{~kg} \mathrm{ha}^{-1}\right.$ $\mathrm{N}$ and $\left.\mathrm{N} 120=80+20 \mathrm{~kg} \mathrm{ha}^{-1} \mathrm{~N}\right)$. The first and second additional fertilising was carried out at $\mathrm{BBCH}$ stages of barley 30 and 47, respectively. The tillage method 
in all treatments was mouldboard ploughing to a depth of $20 \mathrm{~cm}$. The conventional systems were treated with several synthetic pesticides one to four times during crop growth as required. In the organic systems, weed control was after sowing by hand. In the year after barley, red clover was grown as a main crop. It was cut twice during the vegetation period: first during the first tenday period of June and second during the first ten-day of August. The BBCH stage of red clover for both cuts was 65 , whereas the $1^{\text {st }}$ cut was chopped and spread. The $2^{\text {nd }}$ cut in the last two weeks of August was ploughed into the soil. The above ground biomass samples of barley + red clover were taken from the test plot size of $0.3 \mathrm{~m}^{2}$ and red clover crop samples from the test plot size of 1 $\mathrm{m}^{2}$. Samples were taken before harvest every year, from which the grain yield structure elements of barley, above ground biomass of barley and undersown red clover in dry matter (DM), also the above ground biomass of red clover crop in DM were determined. The barley was harvested with a combine harvester Sampo (Finland) with a header width of $2 \mathrm{~m}$, i.e. the test area for grain yield calculation was $20 \mathrm{~m}^{2}$. The number of indicators used in statistical analysis was 84 for each crop ( 7 treatments $\times 4$ replication $\times 3$ years). The samples were dried for $48 \mathrm{~h}$ at $105^{\circ} \mathrm{C}$ for grain yield dry matter measurement.
Chemical analyses. Total nitrogen content of oven-dried manure and grain samples were determined by the dry combustion method on an elemental analyzer varioMAX CNS (Elementar, Germany) (Methods..., 1986). Acid digestion by sulphuric acid solution was used to determine cattle manure total phosphorum and total potassium concentrations. Protein content was calculated by multiplying the $\mathrm{N}$ concentration by 6.25 .

Weather conditions. Meteorological data were collected from an Eerika Meteorological Station approximately $2 \mathrm{~km}$ from the trial site (Tables 2-3). 2013 and 2014 were less favourable for plant growth, with temperature in June $2.8^{\circ} \mathrm{C}$ higher and $2^{\circ} \mathrm{C}$ lower than the long-term average (1969-2015, i.e. $15.4^{\circ} \mathrm{C}$ ), respectively. Temperatures of July in 2015 were $1.9^{\circ} \mathrm{C}$ lower than the long-term average (i.e. $15.4^{\circ} \mathrm{C}$ ), which results in two weeks longer growth period and higher grain yield of cereals also. Total rainfall during the growth period of 2013 and 2015 (May-August) was lower (53 and $74 \mathrm{~mm}$, respectively) than the long-term average of $321 \mathrm{~mm}$. Total rainfall during the growth period of 2014 was $63 \mathrm{~mm}$ higher than average. 2012 was favourable for plant growth, with temperatures similar to the long-term average, but total rainfall during the growth period was $102 \mathrm{~mm}$ higher than usual.

Table 2. Mean temperature in 2012-2015 compared with the long-term average (1969-2015) data*

\begin{tabular}{cccccc}
\hline \multirow{2}{*}{ Month } & \multicolumn{5}{c}{ Mean temperature ${ }^{\circ} \mathrm{C}$} \\
\cline { 2 - 6 } & 2012 & 2013 & 2014 & 2015 & $1969-2015$ \\
\hline January & -6.1 & -7.2 & -7.8 & -1.9 & -5.2 \\
February & -11.2 & -3.6 & -0.3 & -0.8 & -5.6 \\
March & -0.4 & -7.8 & 2.2 & 2.7 & -1.5 \\
April & 5.0 & 3.5 & 6.5 & 5.4 & 4.8 \\
May & 11.6 & 14.8 & 11.9 & 10.2 & 11.4 \\
June & 13.6 & 18.2 & 13.4 & 14.2 & 15.4 \\
July & 18.1 & 17.8 & 19.3 & 17.5 & 16.2 \\
August & 15.3 & 16.9 & 16.8 & 12.5 & 10.9 \\
September & 12.2 & 11.0 & 12.1 & 4.2 & 5.6 \\
October & 5.6 & 6.6 & 5.3 & 3.1 & 0.6 \\
November & 2.6 & 3.5 & 1.5 & 1.4 & -3.1 \\
December & -6.6 & 1.0 & -1.5 & & \\
\hline
\end{tabular}

* - data from Eerika Meteorological Station, Estonia

Table 3. Sum of precipitation in 2012-2015 compared with the long-term average (1969-2015) data*

\begin{tabular}{cccccc}
\hline \multirow{2}{*}{ Month } & \multicolumn{5}{c}{ Sum of precipitation mm } \\
\cline { 2 - 6 } & 2012 & 2013 & 2014 & 2015 & $1969-2015$ \\
\hline January & 30 & 9 & 25 & 30 & 30 \\
February & 18 & 14 & 12 & 12 & 23 \\
March & 39 & 15 & 9 & 69 & 28 \\
April & 42 & 61 & 17 & 62 & 59 \\
May & 82 & 52 & 84 & 39 & 76 \\
June & 101 & 63 & 103 & 61 & 70 \\
July & 74 & 27 & 113 & 51 & 56 \\
August & 87 & 45 & 22 & 59 & 56 \\
September & 58 & 70 & 36 & 54 & 45 \\
October & 45 & 47 & 42 & 46 & 35 \\
November & 50 & 9 & & & \\
December & 9 & & 10 & \\
\hline
\end{tabular}

* - data from Eerika Meteorological Station, Estonia 
Statistical analysis. Correlation, factorial analysis of variance (ANOVA) and two-factor ANOVA were used to test the effect of farming systems and experimental year on grain and biomass yields of barley and red clover crops. Descriptive analysis and Fisher's least significant difference test for homogenous groups were used for testing significant differences between organic and conventional treatments, farming systems and experimental year data. Several data are presented as means of treatments per crop production system (organic and conventional) because of small differences between treatments. The means are presented with their standard errors $( \pm \mathrm{SE})$ (bars in the figures). The level of statistical significance was set at $p<0.05$ unless indicated otherwise.

\section{Results and discussion}

First year of two-year growing period. Farming system influence on the grain yield of barley undersown with red clover. The most important factor affecting yield formation in cereals is the number of plants and productive tillers per unit of area. The crucial period for the formation of barley grain yield is determined by the growth stages of tillering and beginning of stem elongation (Moreno et al., 2003; Křen et al., 2014). Garand et al. (2001) and Känkänen and Eriksson (2007) reported, that undersown red clover did not compete strongly with the main crop and recorded only a modest effect on barley yield.

In this study, the grain yield of barley was significantly influenced by the studied factors; the proportion of variation for farming system and weather conditions was $59 \%$ and $9.5 \%$, respectively. The grain yield of barley was negatively influenced by the biomass yield of the undersown red clover $(r=-0.75, P<0.001)$; positively with the number of productive tillers per $\mathrm{m}^{2}$ and plant $(r=0.65, P<0.001)$, also positively with the number $(r=0.49, P<0.001)$ and mass $(r=0.65, P<0.001)$ of grains per ear. Due to the higher red clover biomass yield in the organic system, the number of barley plants and productive tillers per $\mathrm{m}^{2}$ was $10-18 \%(P<0.01)$ and $10-53 \%(P<0.001)$ lower than that in conventional system, respectively. The mean number of barley plants per $\mathrm{m}^{2}$ over trial years and treatments for the organic and conventional systems was $252 \pm 6$ and $281 \pm 7$, respectively, and the same data for productive tillers per plant were $1.3 \pm 0.03$ and $1.9 \pm 0.07$, respectively. In the organic system, the cultivation of cover crop in offseason period did not increase the number of productive tillers per unit area and plant significantly in comparison with control treatment (Org0), but organic $\mathrm{N}$ applied with cattle manure increased the number of productive tillers per $\mathrm{m}^{2}$ significantly, which was $9-10 \%$ higher than that in other organic treatments (Fig. 1). The mean number of productive tillers per $\mathrm{m}^{2}$ over trial years was $349 \pm 14$ in organic treatment OrgII. In conventional system the different mineral $\mathrm{N}$ fertiliser amounts increased the number of productive tillers per $\mathrm{m}^{2} 13-42 \%$ compared to control treatment of this system. The mean number of productive tillers per $\mathrm{m}^{2}$ over trial years was the highest in conventional treatment N120, i.e. $665 \pm 44$ productive tillers per $\mathrm{m}^{2}$. Availability of mineral $\mathrm{N}$ in early spring improved the initial growth of barley plants, which resulted in higher number of productive tillers per plant and per unit of area (Bender, 2015).

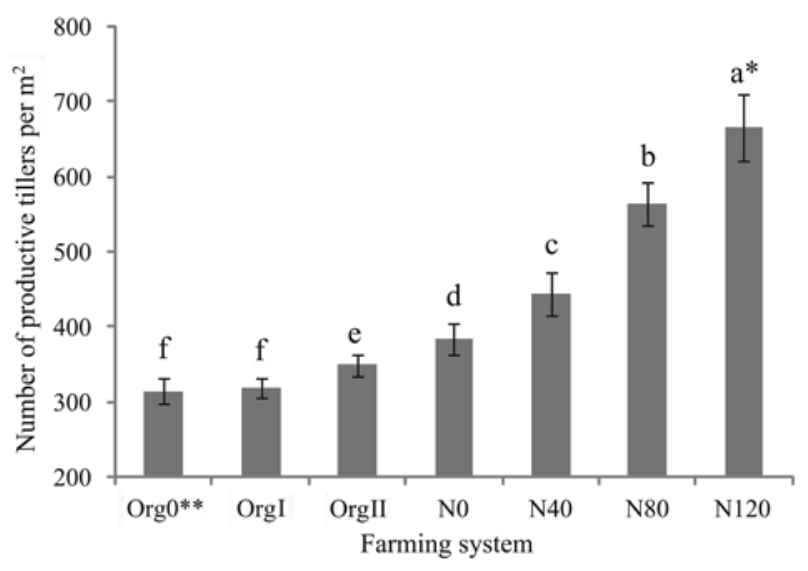

* - different letters denote a significant difference and bars denote $\pm \mathrm{SE} ; * *-\mathrm{N}$ sources during crop cycle period: N0 and $\operatorname{Org} 0=$ symbiotically fixed atmospheric $\mathrm{N}_{2}, \mathrm{~N} 40, \mathrm{~N} 80$ and $\mathrm{N} 120=\mathrm{N}_{2}+$ mineral N 40, 80 and $120 \mathrm{~kg} \mathrm{ha}^{-1} \mathrm{~N}$, respectively; $\operatorname{OrgI}=\mathrm{N}_{2}+\mathrm{N}$ taken up by cover crops $\left(\mathrm{N}_{\mathrm{CC}}\right), \operatorname{OrgII}=\mathrm{N}_{2}+\mathrm{N}_{\mathrm{CC}}$ $+\mathrm{N}$ applied with manure $\left(\mathrm{N}_{\mathrm{m}}\right)$

Figure 1. Mean number of productive tillers of barley over experimental years 2012-2014

In addition to the number of productive tillers per plant, the number and mass of grains per ear are important structural elements for grain yield of cereals. Barley is known as a crop with good adaptability, able to compensate for poorly developed grain yield structure elements in early growing stages with better developed elements later (Moreno et al., 2003). The number and mass of grains per ear were negatively correlated $(r=-0.69$ and $-0.47, P<0.001$ and 0.001 , respectively) with undersown red clover biomass yield. The number of grains per ear in different trial years and treatments of the organic system ranged between 13-21 and in the conventional system between 14-23. The same data for mass of grains per ear were $0.55-1.05 \mathrm{~g}$ and $0.62-1.28 \mathrm{~g}$, respectively. Mean number of grains per ear of the organic system over trial years and treatments was $17 \pm 0.3$, which was $9 \%$ lower than that of conventional system. The same data for mass of grains for organic system was $0.75 \pm 0.02$, which was $18 \%$ lower than that of conventional system. In this field trial, the cultivation of cover crop and application of cattle manure in organic system increased the number and mass of grains per ear up to $14 \%$ and $17 \%$, respectively. Using mineral $\mathrm{N}$ fertiliser in conventional farming system increased the number and mass of grains per ear up to $13 \%$ and $14 \%$, respectively. Cereal grain yield increase with higher $\mathrm{N}$ application may be attributed to increase in leaf area index, above ground biomass and spikes per hectare (Nielsen, Halvorson, 1991).

The grain yield of barley fluctuated in different trial years and treatments in organic and conventional systems between 696-3127 and 1326-5730 $\mathrm{kg} \mathrm{ha}^{-1}$ in DM, respectively (Fig. 2). The highest grain yield in organic and conventional systems was formed in OrgII and N80 treatments, respectively. Cultivation of off-season cover crop winter rye did not result in the higher grain yield, but as an average of trial years the organic $\mathrm{N}$ applied with manure before sowing increased the grain yield of barley 


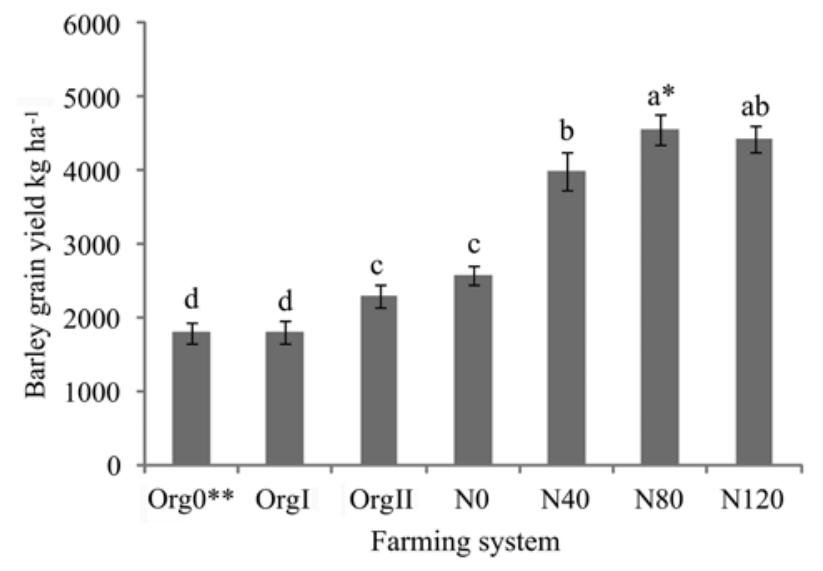

* - different letters denote a significant difference and bars denote $\pm \mathrm{SE} ; * *-\mathrm{N}$ sources during crop cycle period: N0 and $\operatorname{Org} 0=$ symbiotically fixed atmospheric $\mathrm{N}_{2}, \mathrm{~N} 40, \mathrm{~N} 80$ and $\mathrm{N} 120=\mathrm{N}_{2}+$ mineral N 40, 80 and $120 \mathrm{~kg} \mathrm{ha}^{-1} \mathrm{~N}$, respectively; $\operatorname{OrgI}=\mathrm{N}_{2}+\mathrm{N}$ taken up by cover crops $\left(\mathrm{N}_{\mathrm{CC}}\right), \operatorname{OrgII}=\mathrm{N}_{2}+\mathrm{N}_{\mathrm{CC}}$ $+\mathrm{N}$ applied with manure $\left(\mathrm{N}_{\mathrm{m}}\right)$

Figure 2. Mean grain yield of barley over experimental years 2012-2014

$22 \%$ compared to the other organic treatments. Using mineral $\mathrm{N}$ amount $80 \mathrm{~kg} \mathrm{ha}^{-1} \mathrm{~N}$ increased the grain yield of barley $3-43 \%$ compared to the other conventional treatments.

Depending on treatments, the grain yield of barley in the conventional farming system was $11-61 \%$ higher than that in the organic farming system. The mineral nitrogen fertiliser applied at the tillering stage of the cereal plants improves their initial growth, competitiveness and increases the density of cereal plants per unit of area and grain yield (Bender, 2015).

Biomass yield of undersown red clover. Biomass yield of undersown red clover was significantly influenced $(r=0.39, P<0.01)$ only by $\mathrm{N}$ treatment. Using mineral $\mathrm{N}$ fertiliser decreased the red clover biomass yield in conventional system treatments considerably. Mean biomass yield of undersown red clover in the organic farming system over trial years and treatments (Org0OrgII) was $55 \%$ higher than that in the conventional system (Fig. 3). The biomass yield of undersown red clover in the organic system ranged in different trial years and treatments between 1233-2300 kg ha ${ }^{-1}$ in DM and in conventional system amounted up to $1533 \mathrm{~kg} \mathrm{ha}^{-1}$ in DM. The lowest biomass yield of undersown red clover in the conventional system was produced in treatment N120 and the highest in N0 (the mean value over trial years was $200 \pm 111$ and $1817 \pm 166 \mathrm{~kg} \mathrm{ha}^{-1}$ in DM, respectively). Singer et al. (2006) found in their experiment that the high rate of $\mathrm{N}$ reduced red clover final density by $31 \%$. Voisin et al. (2002) reported that mineral $\mathrm{N}$ in the soil inhibited symbiotic nitrogen fixation and nodulation at high concentrations, but far less at lower concentrations. The increase in nitrogen dose usually leads to an increase in the yield of the cereal component, while the share of legume seeds in the yield decreases (Staniak et al., 2014).

Our study revealed that undersown red clover competed strongly with main crop and recorded a strong

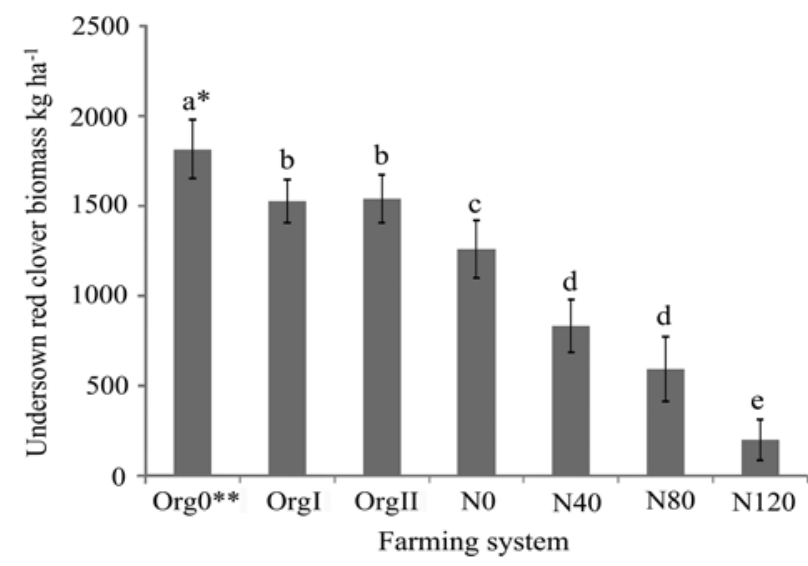

* - different letters denote a significant difference and bars denote $\pm \mathrm{SE} ; * *-\mathrm{N}$ sources during crop cycle period: N0 and $\operatorname{Org} 0=$ symbiotically fixed atmospheric $\mathrm{N}_{2}, \mathrm{~N} 40=\mathrm{N}_{2}+$ mineral $\mathrm{N} 40 \mathrm{~kg} \mathrm{ha}^{-1} \mathrm{~N}, \mathrm{~N} 80=\mathrm{N}_{2}+$ mineral N $80 \mathrm{~kg} \mathrm{ha}^{-1} \mathrm{~N}, \mathrm{~N} 120=\mathrm{N}_{2}+$ mineral $\mathrm{N} 120 \mathrm{~kg} \mathrm{ha}^{-1} \mathrm{~N} ; \operatorname{OrgI}=\mathrm{N}_{2}+\mathrm{N}$ taken up by cover crops $\left(\mathrm{N}_{\mathrm{CC}}\right)$, OrgII $=\mathrm{N}_{2}+\mathrm{N}_{\mathrm{CC}}+\mathrm{N}$ applied with manure $\left(\mathrm{N}_{\mathrm{m}}\right)$

Figure 3. Mean biomass yield of undersown red clover over experimental years 2013-2015

effect on barley grain yield. Probably the seeding rate (2.85 million viable seeds per ha) of the diploid red clover cultivar 'Jõgeva 205' was too high. Bender (2015) reported that seeding rate for tetraploid red clover higher than 1.84 million seeds per ha for undersowing is not considered economical. Higher red clover biomass yield in the organic system caused the smaller number of barley plants and productive tillers per $\mathrm{m}^{2}$ than in conventional system. A higher seeding rate of barley or a lower sowing rate and the later sowing of red clover would be desirable to provide better growing conditions for barley in an organic system. Anderson and Garlinge (2000) reported that competition between plants for water and nutrients may lead to death of tillers.

Protein content of barley. From studied factors the protein content of barley grains was significantly ( $r=$ $0.74, P<0.001)$ influenced only by nitrogen treatments (Fig. 4). Because of the split application of mineral $\mathrm{N}$ the protein content of barley grains as an average of trial years was the highest in the conventional treatment $\mathrm{N} 120$ followed by N80 (114 \pm 2.9 and $99 \pm 2.5 \mathrm{~g} \mathrm{~kg}^{-1}$, respectively). The protein content in organic system ranged between $71.3-96.7 \mathrm{~g} \mathrm{~kg}^{-1}$, whereas the data between treatments were statistically equal. The mean protein content of barley grains over trial years and treatments was $99 \pm 1.6 \mathrm{~g} \mathrm{~kg}^{-1}$ in the conventional system, which was $17 \%$ higher than that in the organic system. The protein content of barley grains was negatively correlated ( $r=$ $-0.58, P<0.001)$ with undersown red clover biomass yield and positively $(r=0.9, P<0.001)$ with barley above ground biomass yield, i.e. higher biomass yield and larger leaf area index of barley result in higher protein content of barley grains, which is consistent with Yoshihira et al. (2002) results. Fuchs et al. (2008) found that compared to the "not-undersown" control treatment the undersown $\mathrm{N}$-fixing crops had no statistically significant effect on the yield and grain protein content and other grain quality 


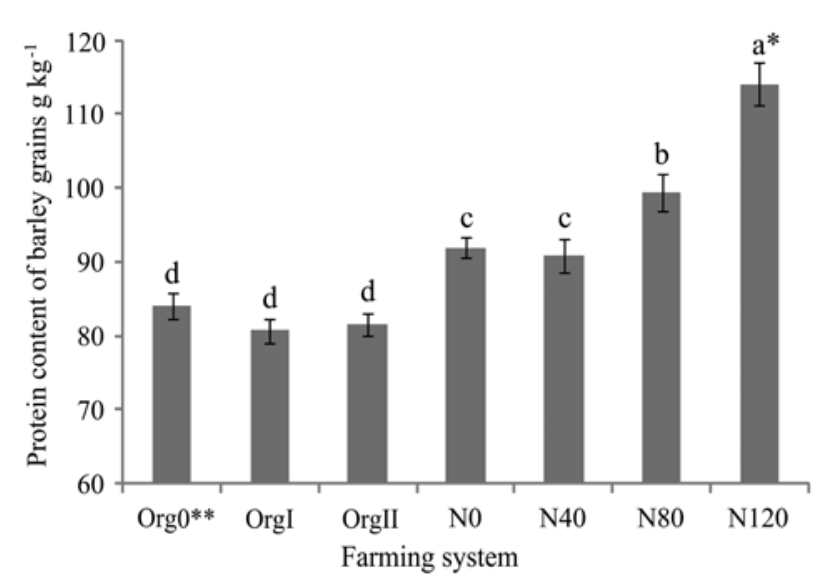

* - different letters denote a significant difference and bars denote $\pm \mathrm{SE} ;{ }^{* *}-\mathrm{N}$ sources during crop cycle period: N0 and $\operatorname{Org} 0=$ symbiotically fixed atmospheric $\mathrm{N}_{2}, \mathrm{~N} 40=\mathrm{N}_{2}+$ mineral $\mathrm{N} 40 \mathrm{~kg} \mathrm{ha}^{-1} \mathrm{~N}, \mathrm{~N} 80=\mathrm{N}_{2}+$ mineral $\mathrm{N} 80 \mathrm{~kg} \mathrm{ha}^{-1} \mathrm{~N}, \mathrm{~N} 120=\mathrm{N}_{2}+$ mineral $\mathrm{N} 120 \mathrm{~kg} \mathrm{ha}^{-1} \mathrm{~N} ; \mathrm{OrgI}=\mathrm{N}_{2}+\mathrm{N}$ taken up by cover crops $\left(\mathrm{N}_{\mathrm{CC}}\right), \operatorname{OrgII}=\mathrm{N}_{2}+\mathrm{N}_{\mathrm{CC}}+\mathrm{N}$ applied with manure $\left(\mathrm{N}_{\mathrm{m}}\right)$

Figure 4. Mean protein content of barley grains undersown with red clover over experimental years 2012-2014

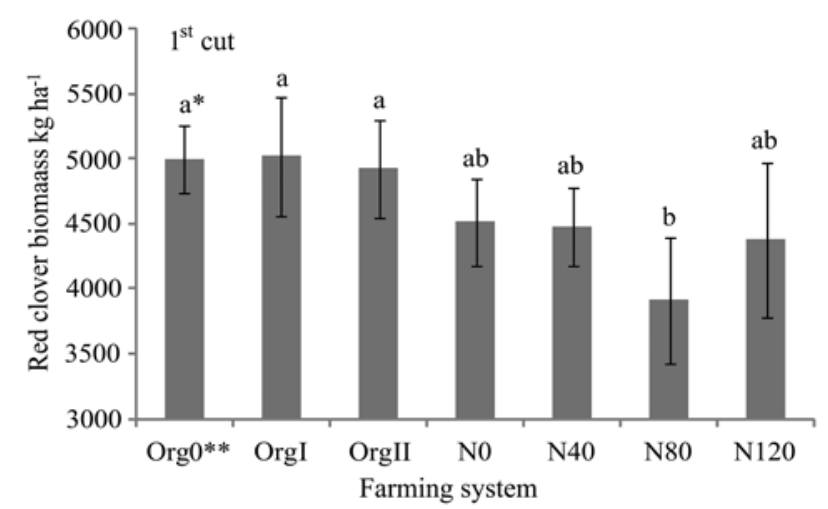

characteristics of the winter wheat crop. In this study in all trial years, undersowing had no significantly positive effect on the grain yield, protein content of barley, which agrees with the results of Fuchs et al. (2008), but were contrary to the results of several studies (HauggaardNielsen et al., 2008; Pridham, Entz, 2008; Corre-Hellou et al., 2011).

Second year of two-year growing period. Biomass yield of red clover crop. In addition to direct effect of mineral $\mathrm{N}$ on growth of undersown legume, the aftereffect of nitrogen on the biomass yield formation of red clover crop was studied. The direct influence of mineral $\mathrm{N}$ in the year of application was shown to have many effects, including a decrease in nodule number, nodule mass, and $\mathrm{N}_{2}$ fixation activity, as well as the acceleration of nodule senescence or disintegration (Ohyama et al., 2012). In this trial, mean biomass yield of the $1^{\text {st }}$ cut in organic treatments over trial years ranged between $4924-5018 \mathrm{~kg} \mathrm{ha}^{-1}$ in DM, which was 9-22\% higher than that in conventional treatments (Fig. 5).

However, the mean biomass yield of the $2^{\text {nd }}$ cut in organic treatments over trial years ranged between

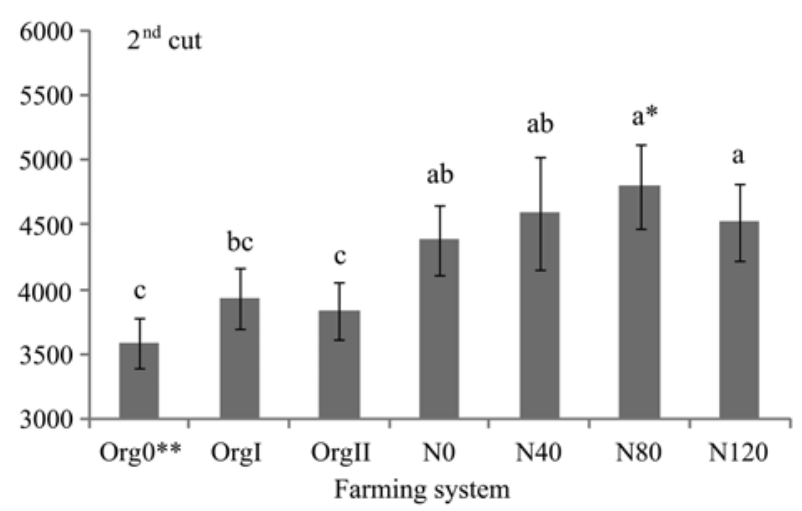

* - different letters denote a significant difference and bars denote $\pm \mathrm{SE} ; * *-\mathrm{N}$ sources during crops cycle period: $\mathrm{N} 0$ and $\mathrm{OrgI}=$ symbiotically fixed atmospheric $\mathrm{N}_{2}, \mathrm{~N} 40, \mathrm{~N} 80$ and N120 $=\mathrm{N}_{2}+$ mineral N 40, 80, $120 \mathrm{~kg} \mathrm{ha}^{-1} \mathrm{~N}$, respectively; OrgII $=\mathrm{N}_{2}+\mathrm{N}$ taken up by cover crops $\left(\mathrm{N}_{\mathrm{CC}}\right)$, OrgIII $=\mathrm{N}_{2}+\mathrm{N}_{\mathrm{CC}}+\mathrm{N}$ applied with manure $\left(\mathrm{N}_{\mathrm{m}}\right)$

Figure 5. Mean red clover biomasses from $1^{\text {st }}$ and $2^{\text {nd }}$ cuts in organic and conventional treatments over experimental years 2013-2015

3588-3939 $\mathrm{kg} \mathrm{ha}^{-1} \mathrm{DM}$, which was 10-20\% lower than that in conventional treatments. The biomass yield of $2^{\text {nd }}$ cut was significantly $(r=0.36, P<0.01)$ influenced by nitrogen treatment. Despite the fact that undersown red clover biomass yield in N120 treatment amounted only to $233 \mathrm{~kg} \mathrm{ha}^{-1} \mathrm{DM}$ in trial years (i.e. 83-87\% lower than that of organic treatments), the red clover crop biomass yield in the next year was in the same treatment statistically comparable ( $1^{\text {st }}$ cut $)$ or higher $\left(2^{\text {nd }}\right.$ cut $)$ with the red clover crop biomass yield of organic treatments. Probably the nitrogen-fixing symbionts inside root nodule cells of legume plants hibernated in the soil, the above ground biomass growth of red clover improved remarkably in the following year, which resulted in higher biomass yield of $2^{\text {nd }}$ cut in conventional treatment fertilised with higher dose of mineral $\mathrm{N}$. Mineral $\mathrm{N}$ fertiliser had no negative aftereffect on symbiosis of legumes with nodule bacteria in the next year or on growth of the red clover crop. Mean above ground biomass yield over trial years for red clover crop ploughed into the soil before sowing of the following crop (i.e. $2^{\text {nd }}$ cut) was $17 \%$ higher in the conventional system than in the organic system. The greater the biomass yield of red clover, the higher the value of symbiotic $\mathrm{N}_{2}$ fixation.

\section{Conclusions}

Our study revealed that undersown red clover competed strongly with the main crop and had a strong effect on the grain yield of barley.

1. The competition for nutrients between cereal and undersown legume resulted in lower density and in lower grain yield of barley in the organic system.

2. A higher sowing rate of barley or a lower sowing rate and later sowing time of undersown red clover would be desirable to provide better growing conditions 
for barley in an organic system. The undersowing rate of 2.85 million red clover seed per ha in this study was probably too high to ensure better growing conditions for barley in the organic system.

3. Mineral $\mathrm{N}$ fertiliser had no negative aftereffect on growth of the red clover crop in the next year. The mean above ground biomass yield over trial years for the red clover crop ploughed into the soil before sowing the following crop ( $2^{\text {nd }}$ cut) was $17 \%$ higher in the conventional system than in the organic system. This result did not confirm our second hypothesis.

4. The content of protein depended on the availability of mineralised N. Undersowing of red clover had no significantly positive effect on the grain yield and protein content of barley. This result did not confirm our first hypothesis.

\section{Acknowledgements}

The study was supported by Estonian University of Life Sciences project 8-2/T13001PKTM, by Estonian Government Target Financing project SF170057s09, by institutional research funding IUT36-2 of the Estonian Ministry of Education and Research, by Era-Net CoreOrganic II project Tilman-Org and by Era-Net CoreOrganic Plus project FertilCrop.

Received 13092016 Accepted 01032017

\section{References}

Alaru M., Talgre L., Eremeev V., Tein B., Luik A., Nemvalts A., Loit E. 2014. Crop yields and supply of nitrogen compared in conventional and organic systems. Agricultural and Food Science, 23: 317-326

Anderson W. K., Garlinge J. R. 2000. The wheat book: principles and practice. Department of Agriculture and Food, Western Australia, Perth. Bulletin 4443, 322 p.

Bender A. 2015. Impact of the seeding and fertilization rates of cover crops and the seedin rate of red clover on the seed yield of the cultivar 'Varte'. Agraarteadus: Journal of Agricultural Science, 1: 3-11

Chinthapalli B., Dibar D. T., Chitra D. S. V., Leta M. B. 2015. Comparative study on the effect of organic and inorganic fertilizers on agronomic performance of faba bean (Vicia faba L.) and pea (Pisum sativum L.). Agriculture, Forestry and Fisheries, 4 (6): 263-268 https://doi.org/10.11648/j.aff.20150406.15

Corre-Hellou G., Dibet A., Hauggaard-Nielsen H., Crozat Y., Gooding M., Ambus Per Dahlmann C., von Fragstein P., Pristeri A., Monti M., Jensen E. S. 2011. The competitive ability of pea-barley intercrops against weeds and the interactions with crop productivity and soil $\mathrm{N}$ availability. Field Crop Research, 122 (3): 264-272 https://doi.org/10.1016/j.fcr.2011.04.004

Fuchs R., Rehm A., Salzeder G., Wiesinger K. 2008. Effect of undersowing winter wheat with legumes on the yield and quality of subsequent winter triticale crops. $16^{\text {th }}$ IFOAM Organic World Congress. Modena, Italy

Garand M. J., Simard R. R., MacKenzie A. F., Hamel C. 2001. Underseeded clover as a nitrogen source for spring wheat on a Gleysol. Canadian Journal of Soil Science, 81 (1): 93-102

https://doi.org/10.4141/S99-060
Hauggaard-Nielsen H., Jørnsgaard B., Kinane J., Jensen E. S. 2008. Grain legume-cereal intercropping: the practical application of diversity, competition and facilitation in arable and organic cropping systems. Renewable Agriculture and Food Systems, 23: 3-12 https://doi.org/10.1017/S1742170507002025

Knudsen M. T., Hauggaard-Nielsen H., Joernsgaard B., Jensen E. S. 2004. Comparison of interspecific competition and $\mathrm{N}$ use in pea-barley, faba bean-barley and lupin-barley intercrops grown at two temperate locations. Journal of Agricultural Science, 142 (6): 617-627 https://doi.org/10.1017/S0021859604004745

Křen J., Klem K., Svobodová I., Míša P., Neudert L. 2014. Yield and grain quality of spring barley as affected by biomass formation at early growth stages. Plant, Soil and Environment, 60 (5): 221-227 https://doi.org/10.1016/j.eja.2007.01.010

Känkänen H., Eriksson C. 2007. Effects of undersown crops on soil mineral $\mathrm{N}$ and grain yield of spring barley. European Journal of Agronomy, 27: 25-34

Methods of soil and plant analysis. 1986. Agricultural Research Centre, Department of Soil Science. Jokioinen, Finland, $45 \mathrm{p}$.

Moreno A., Moreno M. M., Ribas F., Cabello J. 2003. Influence of nitrogen fertilizer on grain yield of barley (Hordeum vulgare) under irrigated conditions. Journal of Agricultural Research, 1: 91-100 https://doi.org/10.5424/sjar/2003011-12

Nielsen D. C., Halvorson A. D. 1991. Nitrogen fertility influence on water stress and yield of winter wheat. Agronomy Journal, 83 (6): 1065-1070 https://doi.org/10.2134/agronj $1991.00021962008300060025 \mathrm{x}$

Ohyama T., Fujikake H., Yashima H., Tanabata S., Ishikawa S., Sato T., Nishiwaki T., Ohtake N., Sueyoshi K., Ishii S. 2012. Effect of nitrate on nodulation and nitrogen fixation of soyeban. El-Shemy H. A. (ed.). Soybean physiology and biochemistry. Rijeka, Croatia, p. 333-364

Pridham J. C., Entz M. H. 2008. Intercropping spring wheat with cereal grains, legumes, and oilseeds fails to improve productivity under organic management. Agronomy Journal, 100 (5): 1436-1442 https://doi.org/10.2134/agronj2007.0227

Singer J. W., Casler M. D., Kohler K. A. 2006. Wheat effect on frost-seeded red clover cultivar establishment and yield. Agronomy Journal, 98 (2): 265-269 https://doi.org/10.2134/agronj2005.0037

Song Y. N., Zhang F. S., Marschner P., Fan F. L., Gao H. M., Bao X. G., Li L. 2007. Effect of intercropping on crop yield and chemical and microbiological properties in rhizosphere of wheat (Triticum aestivum L.), maize (Zea mays L.) and faba bean (Vicia faba L.). Biology and Fertility of Soils, 43: $565-574$ https://doi.org/10.1007/s00374-006-0139-9

Staniak M., Księżak J., Bojarszczuk J. 2014. Mixtures of legumes with cereals as a source of feed for animals. Pilipavicius V. (ed.). Organic agriculture towards sustainability https://doi.org/10.5772/58358

Voisin A.-S., Salon C., Munier-Jolain N. G., Ney B. 2002. Effect of mineral nitrogen on nitrogen nutrition and biomass partitioning between the shoot and roots of pea (Pisum sativum L.). Plant and Soil, 242: 251-262 https://doi.org/10.1023/A:1016214223900

Yoshihira T., Karaswa T., Nakatsuka K. 2002. Traits associated with high-yield in inter triticale in Hokkaido, Japan comparison with wheat and rye. B. Nitrogen fertilizer efficiency. Proceedings of the $5^{\text {th }}$ International Triticale Symposium. Radzików, Poland, vol. II, p. 149-160 
ISSN 1392-3196 / e-ISSN 2335-8947

Zemdirbyste-Agriculture, vol. 104, No. 2 (2017), p. 131-138

DOI $10.13080 /$ z-a.2017.104.017

\title{
Miežiai su raudonųjų dobilų įsèliu ekologinès ir tradicinès žemdirbystès sistemose: azoto įtaka pupinių augalų augimui
}

\author{
M. Alaru, L. Talgre, A. Luik, B. Tein, V. Eremeev, E. Loit \\ Estijos gyvybės mokslų universiteto Žemès ūkio ir aplinkos mokslų institutas
}

\section{Santrauka}

Ekologinės ir mažų sąnaudų ūkininkavimo sistemų pagrindinė problema yra azoto $(\mathrm{N})$ trūkumas. Vasarinių javų auginimas su pupinių augalų įsèliu turi teigiamos įtakos dirvožemio derlingumui - pupinių augalų simbiozė su gumbelinèmis bakterijomis jị papildo azotu. Buvo iškeltos dvi hipotezės: 1) raudonųjų dobilų ịsẻlis miežių grūduose didina baltymų kiekị ir 2) mineralinis azotas turi neigiamos įtakos pupinių augalų augimui. Tyrimo tikslas - ekologinejje ir tradicinèje ūkininkavimo sistemose ištirti organinio (galvijų mèšlo bei antsèlinių nesezono augalų) ir mineralinio azoto įtaką (i) sėjamujų miežių (Hordeum vulgare L.) grūdų derliui ir kokybei, (ii) įsètų raudonųjų dobilų (Trifolium pratense L.) biomasès derliaus formavimuisi ir (iii) mineralinių bei organinių azoto trąšų įtaką raudonųų dobilų biomasès derliui kitais metais.

Eksperimentas atliktas Estijos gyvybès mokslu universitete $\left(58^{\circ} 22^{\prime} \mathrm{N}, 26^{\circ} 40^{\prime} \mathrm{E}\right), 2008 \mathrm{~m}$. ịrengtas lengvo priemolio granuliometrinès sudèties išplautžemyje (Stagnic Albic Luvisol, LV ab-st) (WRB, 2014): C - 1,38 \%, $\mathrm{N}-0,13 \%, \mathrm{P}-133 \mathrm{mg} \mathrm{kg}^{-1}, \mathrm{~K} 210 \mathrm{mg} \mathrm{kg}^{-1}, \mathrm{pH}_{\mathrm{KCl}} 6,0$. Augalai auginti taikant skirtingas ūkininkavimo sistemas: tris ekologines (Org0, OrgI ir OrgII) ir keturias tradicines (N0, N40, N80 ir N120). Per rotacija azoto šaltiniai buvo: N0 ir Org0 = simbiotiškai fiksuotas atmosferos $\mathrm{N}_{2}, \mathrm{~N} 40=\mathrm{N}_{2}+$ mineralinis $\mathrm{N} 40 \mathrm{~kg} \mathrm{ha}^{-1} \mathrm{~N}, \mathrm{~N} 80=\mathrm{N}_{2}+$ mineralinis $\mathrm{N} 80 \mathrm{~kg} \mathrm{ha}^{-1} \mathrm{~N}, \mathrm{~N} 120=\mathrm{N}_{2}+$ mineralinis $\mathrm{N} 120 \mathrm{~kg} \mathrm{ha}^{-1} \mathrm{~N}$, OrgI $=\mathrm{N}_{2}+\mathrm{N}$ sunaudotas antsélinių augalu $\left(\mathrm{N}_{\mathrm{CC}}\right)$ ir $\operatorname{OrgII}=\mathrm{N}_{2}+\mathrm{N}_{\mathrm{CC}}+\mathrm{N}$ gautas su mėšlu $\left(\mathrm{N}_{\mathrm{m}}\right)$. Tyrimo duomenimis, raudonųjų dobilų ịsèlis turèjo reikšmingą įtaką miežių grūdų derliui: konkuruojant dèl maisto medžiagų javų ir pupinių augalų mišinyje miežių grūdų derlius ekologinèje sistemoje buvo 11-61\% mažesnis nei tradicinèje. İsètujų raudonųjų dobilų sèklos norma $(2,84 \mathrm{mln}$. daigių sėklų ha ${ }^{-1}$ ) buvo per didelè. Baltymų kiekis priklausè nuo mineralinio azoto įsisavinimo. Tyrimo metais ir variantuose miežių grūduose vidutinis baltymų kiekis buvo $99 \pm 1,6 \mathrm{~g} \mathrm{~kg}^{-1}$ tradicinejje sistemoje, t. y. $17 \%$ daugiau nei ekologinèje. Miežių grūdų derliui ir baltymų kiekiui raudonųjų dobilų ịsėlis reikšmingos teigiamos ịtakos neturejjo. Mineralinès azoto trąšos neturejjo neigiamos įtakos raudonuju dobilu augimui kitais metais. Vidutinis antžeminès raudonųjų dobilų antrosios pjūties biomasės derlius bandymų metais buvo $17 \%$ didesnis tradicinejje sistemoje nei ekologinèje.

Reikšminiai žodžiais: baltymų kiekis javų grūduose, konkurencija dèl maisto medžiagų, sẻklos norma ir sėjos laikas. 